\title{
Adsorption of Acid Blue-7 Dye from Aqueous Solution On to Teak Sawdust And its Analysis By Equilibrium Adsorption Isotherms And Thermodynmics Equations
}

\author{
Kapil Malviya ${ }^{1}$, Dr. Charu Parashar ${ }^{2}$, Dr. Savita Dixit ${ }^{3}$, Dr. Suneet Kaur ${ }^{4}$ \\ ${ }^{I}$ Ph.D. Scholar, Department of Civil Engg., M.A.N.I.T., Bhopal, M.P., INDIA \\ ${ }^{2}$ Professor, Department of Civil Engg. M.A.N.I.T., Bhopal, M.P., INDIA \\ ${ }^{3}$ Professor, Department of Chemistry M.A.N.I.T., Bhopal, M.P., INDIA \\ ${ }^{4}$ Associate Professor, Department of Civil Engg., M.A.N.I.T., Bhopal, M.P., INDIA
}

\begin{abstract}
The treatment of Acid Blue-7 dye by a adsorbent of Teak sawdust on the various parameters like adsorbent dosage, $\mathrm{pH}$, temperature, agitation speed, sieve size and contact time which removes the colour of Acid Blue-7 dye used in textile industry. The results were evaluated with the use of equilibrium, kinetic and thermodynmics equations. The sorption data were then correlated with the Langmuir, Freundlich and Tempkin adsorption isotherm models. The Langmuir and Freundlich isotherms are exhibited a better fit for the adsorption data than the Temkin isotherm, and thermodynamic equation were analysed by Langmuir constant at varying temperatures. The maximum colour removal from the wastewater was obtained at an optimum adsorbent dosage of $1000 \mathrm{mg}$ with 120 mins contact time.
\end{abstract}

Keywords: Acid Blue-7, Teak sawdust, Concentration, pH, Contact Time, Sieve size.

\section{Introduction}

Dye affected waterbodies from expansion of industrial productivities are a threat to the modern civilisation since the dyes can impose severe illness and also depreciate the nature of the territorial waters, terrible for freshwater and marine water ecosystems [Gupta et al., 2010]. Colour discharges on the waterbodies even in small amount can creates huge problems e.g. photosynthetic processes of aquatic plants, deficiency of dissolved oxygen levels in water and in critical cases promotes the asphyxiate of aquatic flora and fauna in natural receivers. Furthermore, many organic compounds contains dyes in form of phenolic [Abburi, 2003], organic acids [Deosarkar, 2004], hydrocarbons [Xu et al., 1997], alkenes [Long et al., 2008] etc. which are creating mutagenicity, carcinogenicity and teratogenicity diseases. Dyes are recalcitrant molecules [Ozacar and Sengil, 2003], which required special treatments to remove them. For those kinds of pollutants, the accessible treatments have adsorption [Lee et al., 2005], coagulation/flocculation [Leiknes, 2009], ion-exchange [Klaysom, 2011], filtration [Laasri et al., 2007] etc. Out of these treatments the adsorption process is generally used on coloured wastewater due to viability of adsorbents making materials.

In present years, a different variety of materials such as neem sawdust [Khattri and Singh, 2009]; eucalyptus camaldulensis barks [Balci et al., 2011]; jack fruit peel [Hameed, 2009], sawdust [Hanafiah et al., 2012] and wheat shells [Bulut et al., 2007] are used for the removal of various dyes. In this analysis, the use of teak sawdust as an adsorbent for basic dye removal from aqueous solutions was studied. The effect of parameters such as dosage of the adsorbent, contact time, concentration of dye, temperature and $\mathrm{pH}$ on the adsorption capacity was determined. The equilibrium, kinetics and thermodynamics equations have been used for the analysis.

\section{A. Dye Structure}

\section{Materials And Methods}

Acid Blue-7 is the sodium salt of 4-Formylbenzene-1, 3-disulfonic acid and N-benzyl-N-ethyl benzenamine (formula: $\mathrm{C}_{37} \mathrm{H}_{35} \mathrm{~N}_{2} \mathrm{NaO}_{6} \mathrm{~S}_{2}$; molecular weight: 690.81g/mol) [Malviya et al., 2015] was used and purchased from Chemical Market New Delhi, India as shown in Fig 1.

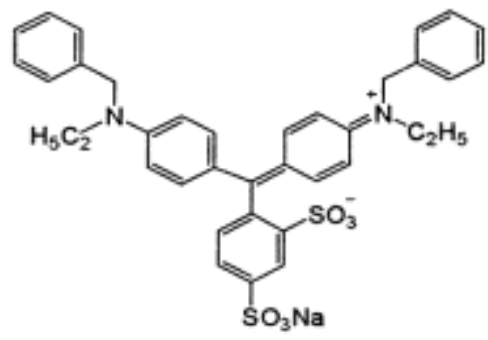

Fig 1 Acid Blue-7 dye structure 
Adsorption of Acid Blue-7 Dye From Aqueous Solution Onto Teak Sawdust And its Analysis By..

\section{B. Preparation of Adsorbent}

Low cost adsorbent teak sawdust is used in this analysis. Teak sawdust was taken from local sawmill. It was rinsed with distilled water and then dried in electrical oven at $50^{\circ} \mathrm{C}$ temperature for one hour duration. Finally, these samples were taken and then milled and crushed to make finer powder which passed from (300150) $\mu,(150-75) \mu$ and $<75 \mu$ sieves. Those adsorbent were packed in plastic packets to avoid preventing moisture entering into the dried adsorbent.

\section{Dye solution preparation}

Weighed quantity of the dye was dissolved in distilled water to prepare the stock solution $(10 \mathrm{mg} / \mathrm{L})$. Make five dilution samples of different concentration (10 to $50 \mathrm{mg} / \mathrm{L})$ from stock solution.

\section{Effects of Adsorbent dosage}

The adsorption of dyes increased with the adsorbent dosage and reached an equilibrium value at 1000 mg of adsorbent dosage (Fig. 2). The percentage of dye removal increased with the increasing amount of dosage of the sawdust. When the sawdust was increased from 1000 to $2000 \mathrm{mg}$, the ratio of dye adsorbed to sawdust $(\mathrm{mg} / \mathrm{g})$ showed decrease in the rate of adsorption.

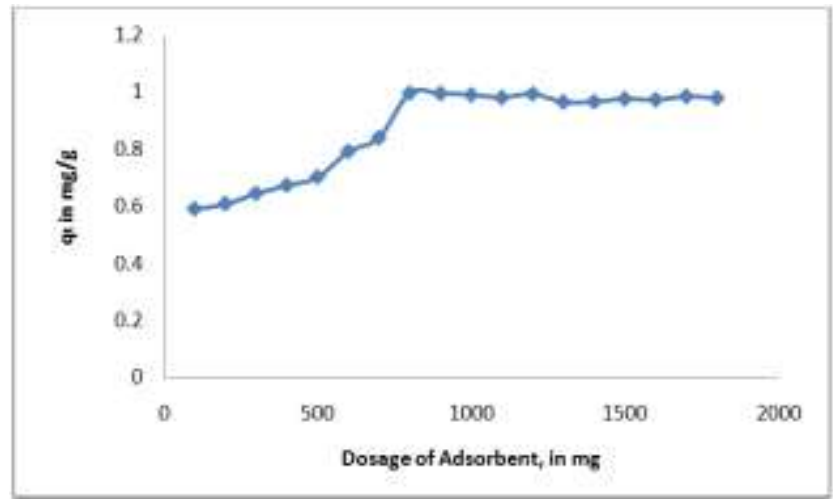

Fig 2 Effects of Adsorbent dosage

\section{E. Effect of particle size}

The size of particle of the adsorbent gives total surface area required for the adsorption and it is the essential factor for controlling adsorption process. The effect of particle sizes were studied and results are presented in (Fig. 3) on the adsorption of Acid Blue-7. The adsorption process revealed that the removal of Acid Blue-7 dye increased with increase in particle size of Teak Sawdust. This can be attributed to larger total surface area of coarser particles for the same quantity of adsorbent [Namasivayam and Arasi, 1997]. This correlation indicates that powdered coarser adsorbent range (300-150) $\mu \mathrm{m}$ would be beneficial over finer particles range in adsorption of Acid Blue-7dye.

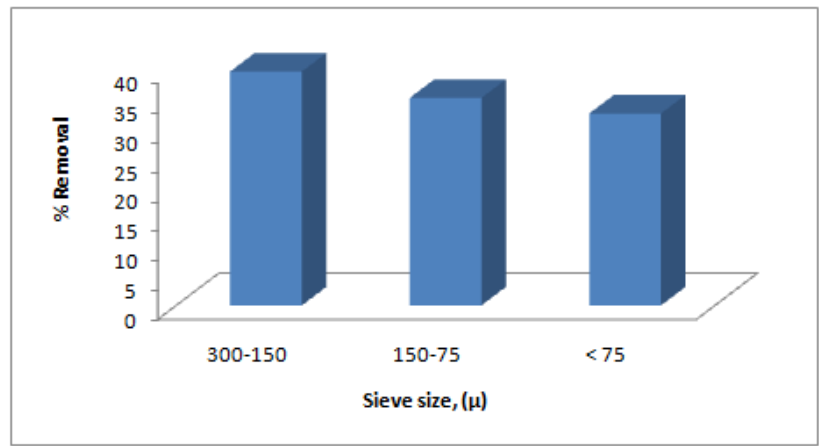

Fig 3 Effects of Sieve size

\section{F. Effect of $\mathrm{pH}$}

In order to study the effect of $\mathrm{pH}$ on Acid Blue-7 adsorption on sawdust, experiments were conducted at varying $\mathrm{pH}$ range of 2 to 12 with $10 \mathrm{mg} / \mathrm{l}$ initial dye concentration with $1000 \mathrm{mg}$ teak sawdust at the temperature $\left( \pm 30^{\circ} \mathrm{C}\right)$ for the $30 \mathrm{~min}$. initial contact time. As shown in Fig 4, the percentage of dye concentration removal increased from $\mathrm{pH} 2$ to $\mathrm{pH} 10$. After $\mathrm{pH}$ above 10, the percentage removals were not significant for dye concentration removal. All $\mathrm{pH}$ measurements were carried out using a digital $\mathrm{pH}$ meter, $0.1 \mathrm{~N} \mathrm{HCl}$ and $0.1 \mathrm{~N}$ 
$\mathrm{NaOH}$ solutions were made for adjusting acidity and alkalinity. On $\mathrm{pH} 10 \pm 0.5$ adsobent gives better removal efficiency as shown in Fig 4 also.

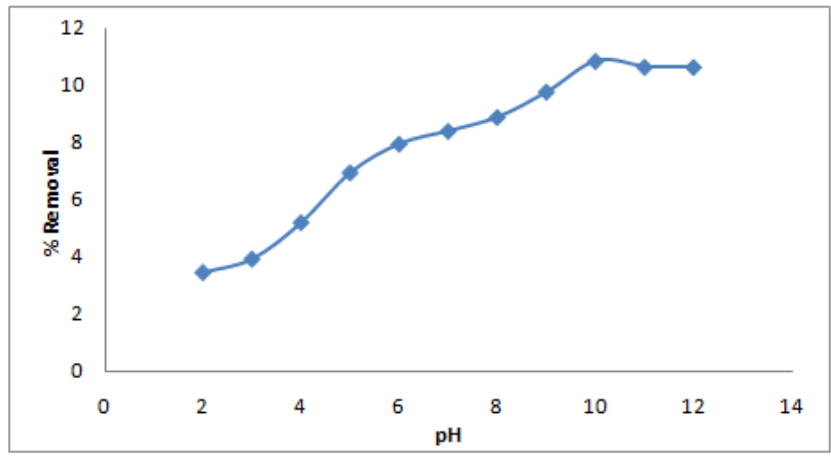

Fig 4 Effects of $\mathrm{pH}$

\section{G. Adsorption procedure}

Batch studies were performed at $30^{\circ} \mathrm{C}$ temperature in a set of Conical flasks $(200 \mathrm{ml})$ with different concentrations (10-50 mg/L) of Acid Blue-7 dye. Teak sawdust of $1000 \mathrm{mg}$ was measured into each of the flasks and the $(10 \pm 0.5) \mathrm{pH}$ of the dye solution was maintained. Thereafter, the Aluminum foil was used to cover all flasks, which were placed in a water bath shaker at $30^{\circ} \mathrm{C}$ temperature with constant speed of $110 \mathrm{rpm}$. After $120 \mathrm{mins}$ of agitation, equilibrium condition Fig 5. Samples were taken, filtered to determine concentration of the dye left in the solution with the aid of UV-Vis spectrophotometer.

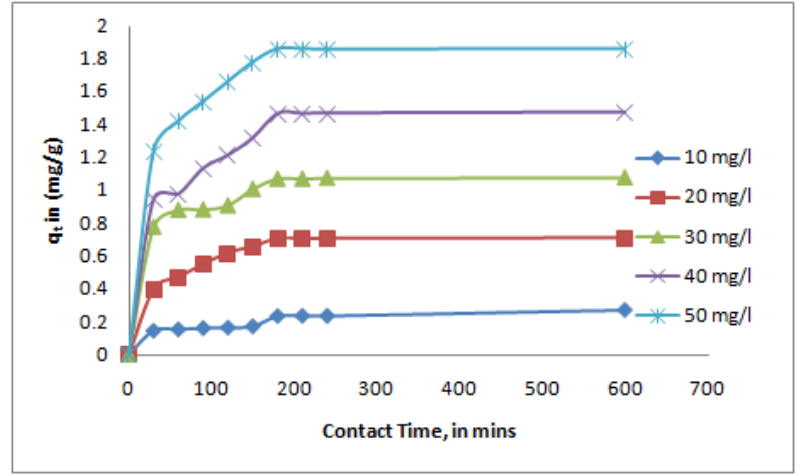

Fig 5 Equilibrium Adsorption study

The amount of dye removed by sawdust biomass at equilibrium time $\mathrm{t}, \mathrm{q}_{\mathrm{e}}(\mathrm{mg} / \mathrm{g})$ and $\mathrm{q}_{\mathrm{t}}(\mathrm{mg} / \mathrm{g})$ was calculated by the following mass balance [Behnajady et al., 2007], [Neelavannan et al., 2007] relationships:

$\mathrm{q}_{\mathrm{e}}=\frac{\left(\mathrm{C}_{0}-\mathrm{C}_{\mathrm{e}}\right) \mathrm{V}}{\mathrm{W}}$

$\mathrm{q}_{\mathrm{t}}=\frac{\left(\mathrm{C}_{0}-\mathrm{C}_{\mathrm{t}}\right) \mathrm{V}}{\mathrm{W}}$

And dye removal efficiency i.e. \% of adsorption was calculated [Garg et al., 2004] as

$\%$ Removal $=\frac{\left(\mathrm{C}_{0}-\mathrm{C}_{\mathrm{t}}\right)}{\mathrm{C}_{0}} \mathrm{X} 100$

where $C_{0}$ is the initial dye concentration $(\mathrm{mg} / \mathrm{L}), \mathrm{C}_{\mathrm{t}}$ is the concentration of dye at any time $\mathrm{t}, \mathrm{V}$ is the volume of solution in $(\mathrm{L})$ and $\mathrm{W}$ is the weight of Teak Sawdust in $(\mathrm{gm})$.

\section{A. Equilibrium Adsorption study}

\section{Results}

Equilibrium adsorption data has been used for adsorption isotherms study. These data describes the rate of the reaction and the adsorption mechanism and affinity of the adsorbent. Thermodynamic studies gives information about the reaction whether it is endothermic or exothermic and spontaneity of the adsorption process. The importance of obtaining the isotherm becomes more and more significant, because as more 
applications are developed, more accurate and detailed isotherm descriptions are required for the adsorption system designs.

\section{B. Langmuir Adsorption Isotherm}

Equilibrium Adsorption Isotherm which exhibit the relationship between mass of adsorbate adsorbed per unit weight of adsorbent and liquid-phase equilibrium concentration of adsorbate are represented by adsorption isotherms and provide important design data for adsorption system. The equilibrium data for removal of acid blue-7 in the present considerations were analysed using Langmuir adsorption [Oladoja et al., 2008] model:

$\mathrm{q}_{\mathrm{e}}=\frac{\mathrm{q}_{0} \mathrm{bC}_{\mathrm{e}}}{1+\mathrm{bC}}$

On rearranging this equation we get

$\frac{\mathrm{C}_{\mathrm{e}}}{\mathrm{q}_{\mathrm{e}}}=\frac{\mathrm{C}_{\mathrm{e}}}{\mathrm{q}_{0}}+\frac{1}{\mathrm{~b} \mathrm{q}_{0}}$

where parameters $\mathrm{q}_{\mathrm{e}}$ is the amount of adsorbate in the adsorbent at equilibrium $(\mathrm{mg} / \mathrm{gm}), \mathrm{C}_{\mathrm{e}}$ the equilibrium concentration $(\mathrm{mg} / \mathrm{L}) . \mathrm{q}_{0}$ and $\mathrm{b}$ are the Langmuir constants related to maximum achievable adsorption capacity (monolayer capacity) and bonding energy of adsorption (or affinity between the sorbate and sorbent). The above equation can be linearized to get the maximum capacity, by plotting a graph of $\mathrm{C}_{\mathrm{e}} / \mathrm{q}_{\mathrm{e}} \mathrm{Vs} \mathrm{C}_{\mathrm{e}}$.

The essential characteristics of the Langmuir isotherm can be expressed in terms of a dimensionless equilibrium parameter $\left(\mathrm{R}_{\mathrm{L}}\right)$ [Adamson, 1990], which is defined by:

$$
\mathrm{R}_{\mathrm{L}}=1 /\left(1+\mathrm{b} \mathrm{C}_{\mathrm{o}}\right)
$$

where $b$ is the Langmuir constant and $C_{o}$ the highest dye concentration $(m g / l)$. The value of $R_{L}$ indicates the type of the isotherm to be either unfavourable $\left(\mathrm{R}_{\mathrm{L}}>1\right)$, linear $\left(\mathrm{R}_{\mathrm{L}}=1\right)$, favourable $\left(0<\mathrm{R}_{\mathrm{L}}<1\right)$ or irreversible $\left(R_{L}=0\right)$. The value of $R_{L}$ is shown in table 1, confirmed that the Teak Sawdust is favorable for adsorption of the Acid Blue-7 dye under conditions used in this study.

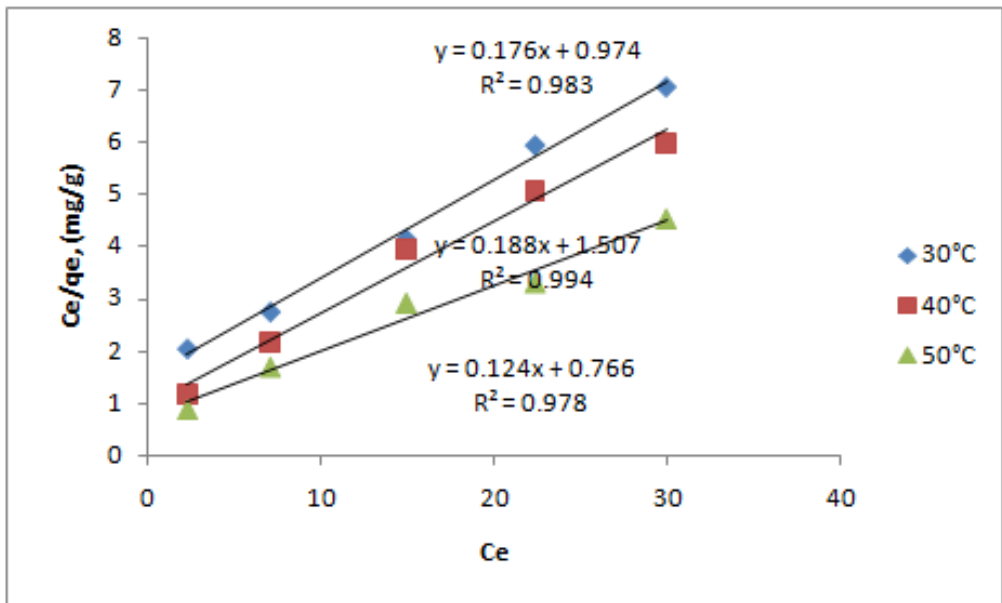

Fig. (6) Langmuir Adsorption Isotherm

Table 1: The values of parameters and correlation coefficient of Langmuir equation

\begin{tabular}{|c|c|c|c|c|}
\hline \multicolumn{5}{|c|}{ Langmuir Adsorption Isotherms Data } \\
\hline Temperature, in ${ }^{\circ} \mathbf{C}$ & $\mathbf{q}_{\max }$ & $\mathbf{b}$ & $\mathbf{R}_{\mathbf{L}}$ & $\mathbf{R}^{\mathbf{2}}$ \\
\hline $\mathbf{3 0}^{\circ} \mathbf{C}$ & 5.68 & 0.18 & 0.356 & 0.983 \\
\hline $\mathbf{4 0}^{\circ} \mathbf{C}$ & 5.319 & 0.124 & 0.445 & 0.994 \\
\hline $\mathbf{5 0}^{\circ} \mathbf{C}$ & 8.064 & 0.161 & 0.381 & 0.978 \\
\hline
\end{tabular}

\section{Freundlich Adsorption Isotherm}

The Freundlich model [Gupta and Babu, 2009] can be applied for non-ideal adsorption onto heterogeneous surfaces involving multilayer adsorption. The linearised Freundlich model isotherm was applied for the adsorption of acid blue-7 and is expressed as:

$\log \mathrm{q}_{\mathrm{e}}=\log \mathrm{K}_{\mathrm{f}}+1 / \mathrm{n} \log \mathrm{C}_{\mathrm{e}}$ 
where $\mathrm{q}_{\mathrm{e}}$ is the amount of dye adsorbed at equilibrium $(\mathrm{mg} / \mathrm{g})$, and $\mathrm{C}_{\mathrm{e}}$ is the equilibrium concentration of dye in solution $(\mathrm{mg} / \mathrm{L}) . \mathrm{K}_{\mathrm{f}}$ and $\mathrm{n}$ are the constants incorporating all parameters affecting the adsorption process (adsorption capacity and intensity).

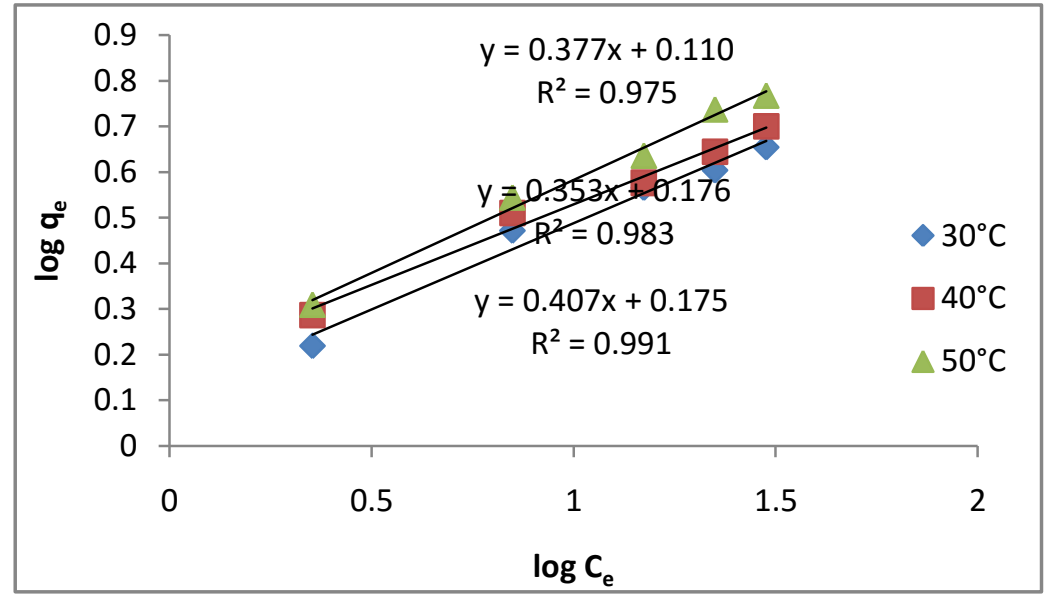

Fig. (7) Freundlich Adsorption Isotherm

Table (2): The values of parameters and correlation coefficient of Freundlich equation

\begin{tabular}{|c|c|c|c|}
\hline \multicolumn{4}{|c|}{ Freundlich Adsorption Isotherms Data } \\
\hline Temperature, in ${ }^{\circ} \mathbf{C}$ & $\mathbf{K}_{\mathbf{F}}(\mathbf{L} / \mathbf{m g})$ & $\mathbf{1} / \mathbf{n}$ & $\mathbf{R}^{\mathbf{2}}$ \\
\hline $\mathbf{3 0}^{\circ} \mathbf{C}$ & 1.496 & 0.407 & 0.991 \\
\hline $\mathbf{4 0}^{\circ} \mathbf{C}$ & 1.499 & 0.353 & 0.983 \\
\hline $\mathbf{5 0}^{\circ} \mathbf{C}$ & 1.288 & 0.377 & 0.975 \\
\hline
\end{tabular}

\section{Thermodynamics Analysis}

The thermodynamic parameters such as change in standard free energy $\left(\Delta G^{\circ}\right)$, enthalpy $\left(\Delta H^{\circ}\right)$ and entropy $\left(\Delta S^{\circ}\right)$ of adsorption were determined using the following equations [Smith and Ness, 1987] :

$$
\begin{array}{lc}
\Delta G^{\circ}=-R T \ln K & {[9]} \\
\Delta H^{\circ}=R\left(T_{2} T_{1}\right) /\left(T_{2}-T_{1}\right) \ln \left(K_{2} / K_{1}\right) & {[10]} \\
\Delta S^{\circ}=\left(\Delta H^{\circ}-\Delta G^{\circ}\right) / T & \text { [11] }
\end{array}
$$

where $R$ is the gas constant, $K_{1}$ and $K_{2}$ the Langmuir constants corresponding to the temperatures 303 $\mathrm{K}, 313 \mathrm{~K}$ and $323 \mathrm{~K}$ and $T$ is the solution temperature in Kelvin. The negative values of $\Delta G^{\circ}$ indicate the degree of spontaneity of the adsorption process. The positive values of $\Delta H^{\circ}$ show that the adsorption is endothermic; the possible explanation for this being displacement of more than one water molecule by the Acid Blue-7 ions for their adsorption, which in turn results in the endothermicity of the adsorption process. The positive value of $\Delta S^{\circ}$ suggests increased randomness at the solid/solution interface during the adsorption of Teak Sawdust towards Acid Blue-7 dye. Also the positive $\Delta S^{\circ}$ value corresponds to an increase in the degree of freedom of the adsorbed species. $K_{1}$ and $K_{2}$ are the Langmuir constants corresponding to the temperature 303, 313 and $323 \mathrm{~K}$. The values of thermodynamic parameters were given in Table 3.

Table 3 : Thermodynamic parameters for the adsorption of Acid Blue-7 dye by teak sawdust

\begin{tabular}{|cccc|}
\hline Temperature $(\mathbf{K})$ & $-\Delta \boldsymbol{G}^{\circ}\left(\mathbf{k J ~ m o l}^{-\mathbf{1}}\right)$ & $\Delta \mathbf{H}^{\circ}\left(\mathbf{k J ~} \mathbf{~ m o l}^{-\mathbf{1}}\right)$ & $\Delta \mathbf{S}^{\circ}\left(\mathbf{k J ~ m o l}^{-\mathbf{1}} \mathbf{K}^{-\mathbf{1}}\right)$ \\
\hline 303 & 4.319 & & \\
313 & 4.462 & 21.948 & 87.63 \\
323 & 4.605 & & \\
\hline
\end{tabular}

\section{Conclusion}

In the present study, it was found that adsorption of Acid Blue-7 dye on teak sawdust at temperatures $\left(30^{\circ} \mathrm{C}, 40^{\circ} \mathrm{C}\right.$ and $\left.50^{\circ} \mathrm{C}\right)$ are better by Langmuir and Freundlich adsorption isotherm. Freundlich adsorption isotherm better fitted than Langmuir adsorption isotherm. The thermodynamic study indicates that the adsorption process at temperatures $30^{\circ} \mathrm{C}, 40^{\circ} \mathrm{C}$ and $50^{\circ} \mathrm{C}$. The positive value of $\Delta \mathrm{H}^{\circ}$ indicates that the adsorption of Acid Blue-7 on teak sawdust is an endothermic process. The negative value of $\Delta G^{\circ}$ showed spontaneous nature of the adsorption. The positive value of $\Delta \mathrm{S}^{\circ}$ suggests increased randomness at the solid solution interface occurs in the internal structure of the adsorption of Acid Blue-7 dye onto teak 
sawdust. The existence of some structural changes at the solid-liquid interface and favours the ion exchange and stability of the adsorption. The enthalpy of adsorption for Acid Blue-7 is 1.

\section{Acknowledgment}

I greatly thankful the Civil Engineering Department, M.A.N.I.T., Bhopal, for providing me with the facilities to carry out my research work.

\section{References}

[1]. Mittal, J. Mittal, A. Malviya, D. Kaur, V.K. Gupta, (2010) Adsorption of hazardous dye crystal violet from wastewater by waste materials, J. Colloid Interface Sci. 343: 463-473.

[2]. W. Adamson, (1990) Physical Chemistry of Surfaces, 5th ed., Wiley, New York,. Pigments, 51: 25-40.

[3]. Balci, O. Keskinkan and M. Avci, (2011) Use of BDST and an ANN model for prediction of dye adsorption efficiency of Eucalyptus camaldulensis barks in fixed-bed system, Expert Systems with Applications 38: 949-956.

[4]. B.H. Hameed, (2009) Removal of cationic dye from aqueous solution using jackfruit peel as non-conventional low-cost adsorbent, J. Hazard. Mater. 162: 344-350.

[5]. Klaysom, S.H. Moon, B.P. Ladewig, G.Q. Max Lu, L. Wang, (2011) Preparation ofporous ion-exchange membranes (IEMs) and their characterizations, J. Membr.Sci. 371: 37-44.

[6]. Long, A.M. Li, H.S. Wu, F.Q. Liu, Q.X. Zhang, (2008) Polanyi-based models for the adsorption of naphthalene from aqueous solutions onto nonpolar polymeric adsorbents, J. Colloid Interface Sci. 319: 12-18.

[7]. Namasivayam, J.S.E. Arasi, (1997) Removal of Congo red from wastewater by adsorption onto waste red mud. Chemosphere, 34: 401-17.

[8]. J.M. Smith, H.C. Van Ness, (1987) Introduction to Chemical Engineering Thermodynamics, McGraw-Hill, New York, USA,

[9]. J.W. Lee, H.J. Jung, D.H.Kwak, P.G. Chung, (2005) Adsorption of dichloromethane from water onto a hydrophobic polymer resin XAD-1600, Water Res. 39: 617-629.

[10]. K. Abburi, (2003) Adsorption of phenol and p-chlorophenol from their single and bisolute aqueous solutions on Amberlite XAD-16 resin, J. Hazard. Mater. B105: 143-156.

[11]. K. Malviya, C. Parashar, S. Dixit, (2015) Removal of acid blue - 7 dye from aqueous solution using water hyacinth as a adsorbent : adsorption equilibrium isotherms, I.J.M.T.E.R., 2.

[12]. L. Laasri, M.K. Elamrani, O. Cherkaoui, (2007) Removal of two cationic dyes from a textile effluent by filtration-adsorption on wood sawdust, Environ. Sci. Pollut. Res.Int. 14 (4): 237-240.

[13]. M.A. Behnajady, N. Modirshahla, F. Ghanbary, (2007) A kinetic model for the decolourization of C.I. Acid Yellow 23 by Fenton process, J. Hazard. Mater. 148: 98-102.

[14]. M.A.K.M. Hanafiah, W.S.W. Ngah, S.H. Zolkafly, L.C. Teong,Z.A. Abdul-Majid, (2012) Acid Blue 25 adsorption on base treated Shorea dasyphylla sawdust: kinetic, isotherm, thermodynamicand spectroscopic analysis, J. Environ. Sci. 24 (2): $261-268$.

[15]. M.G. Neelavannan, M. Revathi, C. Ahmed Basha, (2007) Photocatalytic and electrochemical combined treatment of textile wash water, J. Hazard. Mater. 149: 371-378.

[16]. N.A. Oladoja, I.O. Asia, C.O. Aboluwoye, Y.B. Oladimeji, A.O. Ashogbon, (2008) Studies on the sorption of basic dye by rubber (hevea brasiliensis) seed shell, Turk. J. Eng. Env. Sci. 32: 1-10.

[17]. Ozacar, I.A. Sengil, (2003) Adsorption of reactive dyes on calcined alunite from aqueous solution. J. Hazard. Mater. 98: $211-224$.

[18]. S. Gupta, B.V. Babu, (2009) Removal of toxic metal Cr(VI) from aqueous solutions using sawdust as adsorbent: equilibrium, kinetics, and regeneration studies. Chem. Eng. J. 150: 352-365.

[19]. S.D. Khattri, M.K. Singh, (2009) Removal of malachite green from dye wastewater using neem sawdust by adsorption, J.Hazard.Mater.167: 1089-1094.

[20]. S.P. Deosarkar, V.G. Pangarkar, (2004) Adsorptive separation and recovery of organics from PHBA and SA plant effluents, Sep. Purif. Technol. 38: 241-254.

[21]. T. Leiknes, (2009) The effect of coupling coagulation and flocculation with membrane filtration in water treatment: a review, Journal of Environmental Sciences-China 21: 8-12.

[22]. V.K. Garg, M. Amita, R. Kumar, R. Gupta, (2004) Basic dye (Methylene Blue) removal from simulated wastewater by adsorption using Indian rosewood sawdust. Dyes Pigments. 63: 243-250.

[23]. V.K. Gupta, A. Mittal, (2010) Adsorptive removal and recovery of azo dye erichrome black T, Toxicol. Environ. Chem. 92 (10): 1813-1823.

[24]. Y. Bulut, N. Gözübenli, H. Aydin, (2007) Equilibrium and kinetics studies for adsorption of direct blue 71 from aqueous solution by wheat shells, J. Hazard. Mater.144: 300-306.

[25]. Z.Y. Xu, Q.X. Zhang, C. Wu, L. Wang, (1997) Adsorption of naphthalene derivatives on different macroporous polymeric adsorbents, Chemosphere 35: 2269-2276. 